\title{
Em busca do limiar sonoro: gestos, sons e riscos na afinação das folias ${ }^{1}$
}

\section{Wagner Diniz Chaves}

Universidade Federal do Rio de Janeiro / Rio de Janeiro, R], Brasil

O artigo aborda a afinação dos instrumentos musicais no contexto religioso e festivo das folias na Taboquinha, localidade rural pertencente ao município de São Francisco, norte de Minas Gerais. O texto chama a atenção para a dinâmica envolvida no processo de afinação, entendendo o fenômeno como uma prática coletiva realizada na interação entre pessoas por meio de uma economia expressiva e comunicativa, envolvendo gestos, objetos, movimentos corporais, olhares, palavras e sonoridades. Nessa direção, a pergunta que anima este exercício não é tanto qual é a afinação ou o que é afinação, mas: como se afinam os instrumentos? O que acontece quando a prática é realizada? Quais os efeitos produzidos pela afinação? Como a afinação se relaciona com outras situações e momentos do ciclo ritual das folias? O artigo sugere ainda que a afinação, se por um lado cria um enquadramento, um sentido de coletividade e integração; por outro, é permeada de perigos, riscos e incertezas, fazendo dela uma busca constante, um movimento contínuo, um limiar entre tensões, alturas e frequências.

In search of sound threshold: gestures, sounds and risks in folia tuning

\footnotetext{
ABSTRACT The article deals with the tuning of musical instruments in the religious and festive context of the folias in Taboquinha, a rural locality in the city of São Francisco, northern Minas Cerais. The text draws attention to the dynamics involved in the tuning process, understanding the phenomenon as a collective practice that takes place in interactions between people through an expressive and communicative economy involving gestures, objects, body movements, looks, words and sounds. In this sense, the question that animates this exercise is not so much what the tuning is or what is tuning, but: how the instruments are tuned. What happens when the practice is performed? What effects does tuning produce? How does tuning relate to other situations and moments in the ritual cycle of folias? The article also suggests that tuning, on the one hand creates a framework, a sense of collectivity and integration, on the other is permeated with dangers, risks and uncertainties, making it a constant search, a continuous movement, a threshold between tensions, heights and frequency.
}

DOI

http://DX.DOI.ORG/ $10.11606 / 1678-9857$ RA.2021.186654

1 | Este artigo, fruto de pesquisa etnográfica que desenvolvo há quase duas décadas na região norte/noroeste de Minas Cerais, se beneficiou sobremaneira das sugestões e incentivo de colegas que em diversas ocasiões me ouviram falar sobre a afinação nas folias. Costaria de agradecer em especial a João Miguel Sautchuk, Marco Antonio Conçalves, Tatiana Bacal e Felipe Barros pelas valorosas contribuições. Agradeço ainda aos pareceristas da revista que se dispuseram a ler e comentar a primeira versão do texto.

Ritual, Cultura Popular, Folia, Música, Afinação

KEYWORDS Ritual, Popular Culture Folia, Music, Tuning 
While the laws governing sound movement differ from

melody to melody, from incantation for incantation, the laws have one thing in common: they are dynamic, referring to "states not objects, to relations between tensions, not to position between, to tendencies, not to magnitudes" Paul Stoller, apud Victor Zuckerkandl

É que a música, sendo a mais coletivista de todas as artes, exigindo a coletividade para se realizar, quer com a coletividade dos intérpretes, quer com a coletividade dos ouvintes, está muito mais, e imediatamente, sujeita às condições da coletividade. Mário de Andrade

\section{PRELÚDIO}

Certa vez, como de costume, acompanhava mais um giro de folia quando um de meus interlocutores, ao me explicar a particularidade da folia naquela localidade, me surpreendeu com o seguinte dizer: "A folia aqui na Taboquinha é uma folia cordial". Como sou familiarizado com leituras sobre pensamento social brasileiro, foi inevitável a lembrança do célebre "homem cordial" de Sérgio Buarque de Holanda. Na hora me veio uma inquietação que formulei para mim mesmo: "Mas seria a noção de cordialidade tão profundamente enraizada no nosso imaginário a ponto de um folião no norte de Minas Gerais, com escasso letramento, acioná-la para definir as especificidades das folias na região?"

Ao mesmo tempo em que o termo cordial me remetia ao conceito elaborado pelo autor de Raízes do Brasil, desconfiei que, para meu interlocutor, o termo não tinha o mesmo sentido proposto pelo saudoso historiador. Mas a pergunta persistia: "Em que sentido o termo cordial estava sendo usado naquela situação?” Não foi preciso esperar mais que poucos segundos para o folião, diante da minha visível incompreensão, completar a frase: "Cordial porque a gente usa muitos instrumentos de corda aqui na folia".

Essa anedota seria (e para mim foi por algum tempo) mais uma que nós, antropólogos, colecionamos sem ao certo saber o que fazer com ela. Mas, agora, parece que o "causo" pode colaborar com os rumos da prosa que inspira este escrito. Explico. Ao mencionar como uma característica importante e definidora das folias da região, a existência de muitos instrumentos de corda, meu interlocutor estava me indicando alguns pontos significativos:

1. A dimensão musical é importante na identificação e diferenciação das folias;

2. Os instrumentos de corda funcionam como sinais identificadores das folias da Taboquinha; 
3. Comparativamente, existem folias na região que não se estruturam em torno das cordas.

De fato, ao percorrer muitas localidades do vasto território do norte/noroeste de Minas Cerais, conheci inúmeras folias nos municípios de Januária, Chapada Gaúcha, Urucuia e São Francisco. Pude perceber que em muitos casos, diferentemente do que observava na Taboquinha, a instrumentação dos grupos está centrada na sanfona e a incidência e significado dos instrumentos de corda é menor. ${ }^{2}$

Do conjunto orquestral das folias na Taboquinha contabiliza-se, dentre os instrumentos de corda: três a quatro violas (de dez cordas cada), dois a três violões (com seis cordas cada) e uma rabeca (de cinco cordas). Somando as cordas, chega-se ao total de mais de sessenta. Devemos acrescentar nesse conjunto a caixa que, embora seja um instrumento de percussão, tem um sistema de afinação à base do tensionamento $\mathrm{e}$ afrouxamento das cordas. Partindo da constatação de que as cordas são fundamentais na identidade e sonoridade das folias da Taboquinha, como relacionar esse dado com o fenômeno da afinação? Aonde, afinal, essa conversa com (e através das) cordas pode nos levar?

\section{O GIRO DOS FOLIÕES}

Folias, tais como as peregrinações, procissões, marchas, cortejos, desfiles e romarias são eventos (do e em) movimento. Com diferentes significados e propósitos, todos, de um modo ou de outro, constituem-se por meio da circulação - de pessoas, objetos e símbolos - por determinados espaços em dada temporalidade. No caso das folias, a motivação para a caminhada e viagem dos foliões (termo que nomeia os tocadores e cantadores integrantes de um grupo de folia) é cumprir um giro ou jornada, termos que bem expressam a dinâmica da ação e o ritmo característico do processo ritual.

Com início e fim delimitados por elaborados ritos de abertura e entrega, em geral realizados na casa do dono (ou dona) de uma promessa (imperador ou imperadeira são os termos locais), o giro é organizado com vistas a cumprir um voto assumido com determinada divindade (santo ou santa). Pode-se dizer que um giro resulta no pagamento de uma promessa feita por aqueles que, em contrapartida à graça alcançada, devem organizar e promover uma festa de encerramento daquela folia.

Na região do alto-médio São Francisco, Minas Gerais, muitos são os santos cultuados nas folias. Além da folia de Santos Reis, considerada a primeira e, como veremos, originária das demais, existem folias para muitos santos e santas do panteão católico (São Sebastião, em janeiro; São José, em março; Bom Jesus, em agosto; Nossa Senhora Aparecida, em outubro; Santa Luzia, em dezembro; entre outros), configurando um verdadeiro calendário religioso e festivo ao longo do ano.

Um giro de folia costuma ser encerrado no dia do santo em questão. Por exemplo: 19 de março, no caso de uma folia de São José; 6 de janeiro, para as folias de Santos
2 | Meu contato com o universo

do vale do São Francisco, especialmente em seu curso médio, entre o norte e noroeste de Minas Gerais, remonta ao ano de 2002, quando iniciei pesquisa etnográfica sobre as folias de Santos Reis, Bom Jesus, São José e Santa Luzia. Esta pesquisa resultou em minha tese de doutorado, defendida em 2009 (Chaves, 2009). Entre 2004 e 2005, integrei a equipe do "Celebrações e Saberes da Cultura Popular-Viola de 10 cordas", projeto que elaborou um inventário da viola a partir de pesquisa etnográfica voltada para os processos de fabricação, afinação e modos de tocar o instrumento, bem como para as narrativas e contextos rituais e lúdicos de seu uso. Durante o projeto, coordenado pelo Centro Nacional de Folclore e Cultura Popular (CNFCP/IPHAN), tive a oportunidade de percorrer muitas localidades dos municípios de Januária, São Francisco, Chapada Gaúcha e Urucuia, visitando violeiros, construtores de instrumentos e conhecendo as folias da região. Como desdobramento dessa iniciativa, participei da organização de uma exposição, na Sala do Artista Popular (SAP CNFCP), sobre instrumentos musicais de São Francisco e realizei a pesquisa e produção do filme documentário Seu Minervino e a Viola Caipira. A percepção de diferenciações e variações na estruturação instrumental e musical das folias foi possível graças à participação nesses projetos, que entre outros aprendizados me permitiu estabelecer contato com diversos grupos dessa região marcada por uma impressionante vitalidade e diversidade de folias. 
Reis. Já o início e a duração da folia depende dos termos da promessa feita. Pode durar três, seis, nove ou até doze dias. Durante esse tempo, os foliões deixam seus afazeres cotidianos e moradias e, como se diz, estão no "meio do mundo", percorrendo (a pé, a cavalo, de caminhão, ônibus ou de carro) trilhas, estradas, ruas, atravessando povoados, sítios, fazendas, vilas e cidades.

Na região pesquisada, a caminhada dos foliões deve obedecer a alguns preceitos como: seguir sempre de oriente para ocidente ("pelas direitas" como dizem); não cruzar um caminho já percorrido ("para não apagar rastro"); nem deixar de visitar uma casa situada no percurso escolhido sob pena de castigos e represálias divinas.

Desse modo, a movimentação dos foliões cria um espaço sagrado (um território moral), cujo início e fim acontecem na casa dos festeiros (imperador ou imperadeira). Tendo como referência espacial e simbólica esse local, no correr dos dias e noites, outras casas, assim como igrejas, capelas e cemitérios são visitados e seus moradores (vivos ou mortos) louvados, abençoados e reverenciados. Tais espaços são investidos de sacralidade à medida em que acontece a circulação e troca de bens e serviços entre foliões, moradores, entidades, mortos e antepassados.

Quando a casa de uma família é visitada, por meio da cantoria e movimentação da bandeira (presente em algumas folias como veremos mais adiante), os foliões não somente anunciam a presença da entidade naquele local como, em nome dela, abençoam o lar e os que lá habitam. Em retribuição, os moradores oferecem ao grupo comidas e bebidas (que são consumidas durante a visita), além de ofertas variadas (dinheiro, mantimentos, donativos) para ajudar os donos da promessa a viabilizar os festejos. Essa estrutura relacional, como aponta uma crescente literatura sobre o tema (Brandão, 1981; Reily, 2002; Chaves, 2009; Bitter, 2010; Pereira, 2012, etc.), faz da folia uma modalidade do vasto "sistema das prestações totais" (Mauss, $2003[1925]) .^{3}$

Como se anda, por onde se deve andar, qual o trajeto a ser percorrido, que casas visitar (e quais não visitar), como se deve chegar e como se deve sair de uma casa, todos os procedimentos são investidos de ritmo, significado e eficácia nas folias. O giro, portanto, revela e expressa um saber fazer, variável de acordo com as regiões, localidades e "sistemas" (Pereira, 2014), mas que sempre implica padrões de comportamento, etiqueta, "leis de hospitalidade" (Pitt-River, 2012), além de uma intricada combinação de meios expressivos e comunicativos (Tambiah, 1979) que produz "enquadramentos" e "contextos" (“frames" nos termos de Bateson, 2000 [1955]).

$\mathrm{Na}$ Taboquinha, localidade rural pertencente ao município de São Francisco, onde essa pesquisa foi realizada, uma interessante transformação de "enquadramento" acontece a cada nova visita. A passagem da descontração e informalidade dos foliões quando se deslocam de uma casa para outra à formalidade e solenidade característica da chegada e principalmente da cantoria executada no interior das casas é conduzida e vivenciada por um rito específico - a afinação dos instrumentos musicais.
3 | Brandão que em grande medida inaugura a reflexão antropológica sobre o tema, inspirado na teoria da reciprocidade de Marcel Mauss, interpreta a folia como uma expressão do fenômeno da dádiva: "um espaço camponês simbolicamente estabelecido durante um período de tempo igualmente ritualizado, para efeitos de circulação de dádivas - bens e serviços - entre um grupo precatório e moradores do território por onde ele circula" (1981: 36). Ao se referir a estrutura contratual das visitas que a folia realiza ao longo do giro (repetida em diversos outros momentos do ciclo ritual), Brandão diz: "Cada parada da folia em um giro ou em um pouso repete uma vez mais a mesma sequência de atos: o dono da casa é obrigado a receber os foliões que, por sua vez, são obrigados a se apresentar e a pedir para serem recebidos; o dono da casa é obrigado a recebê-los e a agradecer, abençoandoos por isso; o dono, outros moradores e promesseiros são obrigados a dar alguns dos seus bens como ofertas pedidas, e os foliões são obrigados a retribuir distribuindo bênçãos, proclamando o feito e atualizando promessas aos reis" (1981:45). 
Prática coletiva, realizada nas proximidades do local a ser visitado, a afinação é uma espécie de "rito de passagem" (Van Cennep, 2011 [1908]), que estabelece o vínculo entre a circulação realizada entre as casas e a movimentação que acontece no interior delas. A rigor, nessa localidade nenhuma nova visita é iniciada sem que antes os foliões tenham se reunido e juntos, como dizem, acertado (demoradamente) as violas, rabecas, violões e caixas. Acertar ou afinar os instrumentos significa buscar um equilíbrio possível na qualidade da comunicação e interação entre as pessoas. $O$ canto (momento de maior sacralidade e emotividade de uma visita, pois é quando a presença do santo é anunciada) não é iniciado sem que esse acerto seja alcançado e reconhecido. Na Taboquinha, diferentemente de outras localidades que visitei, o cuidado, apuro e seriedade com os quais os foliões afinam seus instrumentos sempre me chamaram a atenção. ${ }^{4}$

Participando dos giros na Taboquinha, a sensação que eu tinha era de que a intenção (e a eficácia) da prática não se limitava a deixar os instrumentos aptos à performance do canto. Sentia que algo mais estava acontecendo quando os foliões se juntavam e durante um tempo (que poderia se alongar por vários minutos) se empenhavam na atividade. Na afinação, enquanto os instrumentos eram acertados, as pessoas se aproximavam, se reuniam e assim se preparavam para o que estava por vir.

Neste artigo, meu objetivo é descrever e analisar a dinâmica relacional envolvida no processo de afinação. Entendo o fenômeno como uma atividade, um acontecimento e prática coletiva realizada a partir e na interação entre pessoas, sonoridades, materialidades e espacialidades. Posso dizer que meu interesse reside menos na afinação como um produto, ou seja, na relação mensurável entre notas e sons (como diante da pergunta "Qual a afinação desse instrumento?", responde-se "Está em dó", por exemplo), e mais no afinar como um processo e um fazer (Small, 1998). ${ }^{5}$

Desse modo, a pergunta que anima esta reflexão não é tanto qual é a afinação das folias ou o que é afinação, mas: como se afinam os instrumentos e o que acontece quando a prática é realizada? Quais são os efeitos que a afinação produz? De que modo ela se relaciona com outras situações rituais? Quais os riscos, ameaças e perigos que podem incidir sobre a prática?

Em um plano geral e comparativo, meu interesse ao pensar a afinação em sua incessante (e nem sempre bem sucedida) busca por sintonizar, enquadrar e ajustar as diferenças, aproximando pessoas, coisas, temporalidades, sensorialidades e forças, é oferecer elementos para que possamos avaliar as potencialidades e os limites do diálogo - assunto que parece especialmente relevante nesse momento de tantas incertezas e provações em que se percebe, por um lado, a ausência de escuta e disponibilidade para o diferente e, por outro, a proliferação e amplificação de vozes e discursos autoritários, extremistas e negacionistas. Nesse cenário, será que ao observar e, principalmente, ouvir os foliões, que tanto prezam e buscam na afinação um ideal para a convivência entre as pessoas, as coisas e o cosmos, não teremos algo a aprender?
$4 \mid$ Em muitas localidades que visitei, a afinação é realizada de modo mais informal e relaxado. No caso das folias que usam sanfona, como trata-se de um instrumento de afinação fixa, é ela que orienta a afinação dos demais instrumentos. Em regiões onde não há sanfona, mas, em contrapartida, afinador eletrônico ou aparelhos como referência, o processo de afinar é menos ritualizado e tem menor investimento coletivo. No limite, cada músico afina individualmente seu instrumento e depois se reúne brevemente com o grupo para um acerto geral. $\mathrm{Na}$ Taboquinha, distintamente, já que se observa uma grande quantidade de instrumentos de corda e a não presença de meios eletrônicos para conduzir a afinação, o processo envolve variadas etapas (algumas mais coletivizadas e outras mais individualizadas), sendo intrínseca e

intensamente relacional.

$\mathbf{5}$ | Small (1998), em um interessante estudo sobre os concertos sinfônicos, propõe como objeto da pesquisa etnomusicológica não a música propriamente dita mas o que denomina musicar ("musicking" no original).

Para ele, o termo evidencia o fazer musical, a música enquanto ação e atividade (a esse respeito notar que $o$ verbo "musicking" representa o presente do particípio e o gerúndio do verbo "to music", denotando assim não somente uma ação, mas a ação em curso, em andamento, acontecendo no aqui e agora). Incorporando as sugestões de Small para pensar o fazer dos foliões quando se reúnem e acertam seus instrumentos, meu interesse concentra-se menos na afinação em si e mais no afinar (especialmente no que se passa quando tal ação acontece). Portanto, ao longo deste texto, quando utilizo afinação refiro-me ao ato, à ação de afinar. 
Antes, todavia, de adentrarmos no afinar da folia é importante afinarmos a nossa perspectiva com algumas referências teórico-metodológicas.

\section{AFINANDO A PERSPECTIVA}

A análise das relações entre afinaç̧̃̃es, escalas, melodias e estruturas musicais é uma preocupação antiga e recorrente na história da musicologia comparada. Oliveira Pinto (2001) refere-se assim aos interesses principais dos pesquisadores dedicados ao estudo comparativo das musicalidades nesses primeiros tempos:

No início o interesse científico pela música de outros povos restringia-se principalmente às escalas e aos diferentes sistemas musicais, aos instrumentos e sua afinação, sua utilização e também ao estudo e análise das melodias, que eram transcritas minuciosamente para a grafia da música ocidental (2001: 257).

Dentre os pioneiros desse novo campo emergente, podemos mencionar o químico austríaco Erich Von Hornbostel (1877-1935). À frente do Arquivo Fonográfico de Berlim (Berliner Phonogramm-Archiv) por quase três décadas (entre 1905 e 1933), Hornbostel desenvolveu um influente paradigma para os estudos comparativos das músicas dos povos. Seu método de investigação procurava descrever os sistemas musicais e os percursos de deslocamento (no tempo e espaço) das canções e dos instrumentos, enfatizando justamente os aspectos melódicos da música (Nettl, 2005a [1983]; Blum, 1992; Oliveira Pinto 2004). ${ }^{6}$

O material mobilizado por Hornbostel para realizar suas investigações era fundamentalmente composto de gravações que chegavam em grande fluxo ao Arquivo por meio do envio de registros por parte de etnógrafos, missionários, comerciantes, viajantes e administradores coloniais nos quatro cantos do mundo (Ames, 2003).? O método e procedimento analítico de Hornbostel tiveram ampla e duradoura influência na musicologia comparada e posteriormente na etnomusicologia, que veio se desenvolver em solo norte-americano a partir da segunda metade do século XX. 0 estudo de Hornbostel envolvia basicamente três movimentos: primeiramente, a escuta atenta das gravações e exame dos contornos melódicos das músicas; em seguida, a codificação dos intervalos e tonalidades por meio da comparação de diversos exemplos de sequências melódicas em uma mesma área etnográfica ou em um mesmo povo / tradição musical; finalmente, o acesso às escalas e afinações basilares de um dado sistema musical.

Ao descrever o paradigma de Hornbostel, com especial menção à prioridade atribuída às considerações melódicas como ingresso privilegiado aos sistemas musicais, Nettl (2005a [1983]) diz que ele dava
6| Hornbostel doutorou-se em química pela universidade de Viena e foi um dos precursores da musicologia comparada (ciência que floresceu no final do século XIX em países da Europa, notadamente na Alemanha, que se voltou aos estudos comparativos das músicas de diferentes povos). Também foi assistente do filósofo, psicólogo e musicólogo alemão Carl Stumpf, criador do arquivo fonográfico de Berlim em 1900. Em 1905, Hornboste sucede a Stumpf no arquivo, que posteriormente tornou-se o principal repositório de gravações de música do mundo. Só para se ter uma

ideia da magnitude do projeto, o arquivo, que em 1908 reunia em torno de mil cilindros de cera, em 1918 possuía uma coleção de mais de $10 \mathrm{mil}$ cilindros, "making it the world's largest phonogram collection and the hub of a global exchange network" (Ames, 2003:301). Com a ascensão do nazismo e a perseguição aos estudos e aos estudiosos da musicologia, o destino da coleção foi migrar, juntamente com Ceorge Herzog, aluno de Hornbostel, para os Estados Unidos. O deslocamento

dessas gravações incrementou e originou importantes coleções a exemplo dos arquivos fonográficos das Universidades de Columbia e Indiana (Bastos, 1993).

7| Ames lembra que, entre 1900 e 1912, além de gravações vindas das colônias, importantes sessões de registros foram realizadas em Berlim, local onde era possível ouvir e consumir música não ocidental em diferentes espaços relacionados à nascente indústria do lazer e do entretenimento-como circos, shows itinerantes, cabarés, exibições etnográficas, hotéis e até em zoológicos (2003:301) 
[...] great emphasis on the melodic aspects of the music, particularly on what he calls scales. Enumeration of tones, and the relationship of the tones to a not always thoroughly defined tonic, and, beyond that, the specific intervallic distances, are what he speaks to most frequently and immediately. Throughout his work there is evidence of a feeling of urgency to uncover a theoretical framework that, while often unarticulated, must surely exist in each culture for the creation of melodical material (op. cit: 95).

Percebe-se assim que na perspectiva de Hornbostel, como evidenciam alguns de seus comentadores, o propósito da análise era descrever as diferentes estruturas musicais (ou estrutura teórica das diferentes musicologias) por meio de abstrações como as escalas e afinações, que, por sua vez, eram inferidas a partir dos fenômenos melódicos dissecados em laboratórios ${ }^{8}$.

Além de trabalhar com as gravações que integravam as coleções do Arquivo Fonográfico de Berlim, Hornbostel também contribuiu, sobremaneira, para o desenvolvimento do estudo e classificação dos instrumentos musicais. Juntamente com o musicólogo alemão Curt Sachs, responsável pela coleção de instrumentos musicais do Staatliche Instrumentensammlung, elaborou um sistema de classificação conhecido como sistema Sachs-Hornbostel (1914). Esse sistema, pioneiro nos estudos de organologia, importante campo da musicologia comparada e que vem se dinamizando com renovadas abordagens (De vale, 1990; Irving, 2009; Bates, 2012) é ainda amplamente usado como referência para a classificação dos instrumentos (Seeger, 1987; Travassos, 1987). Um aspecto importante desse estudo - e que nos interessa diretamente - é justamente a possibilidade de descrever a afinação e as escalas tendo como base a morfologia dos instrumentos, bem como a sonoridade que eles produzem?

Desdobramento direto das práticas de colecionar instrumentos e gravações realizadas em contextos coloniais e imperiais, tais estudos permitiram à musicologia uma visão menos eurocêntrica e mais nuançada acerca do fenômeno sonoro e das estruturas musicais. Entretanto, como lembra Nettl (2005a), essas pesquisas, ao privilegiarem as melodias, escalas, afinações e outras abstrações fundamentais à imaginação musical do ocidente como critérios para delimitação dos sistemas musicais "exóticos", acabava por reificar a própria noção de música.

No contexto da pesquisa musicológica no Brasil, o tema da afinação aparece nos trabalhos do folclorista, musicólogo e pesquisador Luiz Heitor Correa de Azevedo ${ }^{10}$. Em sua proposta metodológica para coleta e análise do folclore musical, seguindo as recomendações do etnomusicólogo norte-americano Alan Lomax, Luiz Heitor valorizava como fontes principais as gravações e análises dos instrumentos musicais. Se observarmos os modelos das fichas por ele elaborada e utilizadas em suas pesquisas de campo, veremos que, assim como em Hornbostel, a descrição das melodias populares era a via de acesso privilegiada para o estudo das escalas, tonalidades e estruturas musicais.
$8 \mid$ A primazia das

considerações melódicas na definição das escalas, afinações e sistemas musicais, abordagem desenvolvida por Hornbostel, já havia sido defendida anteriormente pelo físico inglês Alexander ]. Ellis, em um estudo publicado no ano de 1885, "On the musical scales of various nations". Nettl (2005b) considera esse texto um marco na história da musicologia comparada e, consequentemente da etnomusicologia.

9| No sistema SachsHornbostel, os instrumentos são classificados em quatro grandes grupos (idiofones, membrafones, cordofones e aerofones), que se subdividem em uma série de níveis e subníveis (Hornbostel e Sachs, 1961 [1914]).

10| A trajetória bem como o trabalho etnográfico e colecionista de Luiz Heitor Corrêa de Azevedo foram temas abordados nas pesquisas de Aragão (2005), Barros (2013) e Mendonça (2007), entre outros. 
Quanto aos instrumentos musicais, a recomendação de Luiz Heitor era descrevêlos do ponto de vista morfológico (com atenção especial às suas dimensões, à nomenclatura das suas partes, etc.). Em relação aos instrumentos de corda, aconselhavase ainda que o pesquisador indicasse o som (e a nota equivalente) de cada corda individualmente, para, em seguida, pela comparação entre os sons das diferentes cordas, traçar o sistema de afinação.

Na publicação "Relação dos discos gravados no estado de Goiás", de 1950, na seção "textos e comentários", encontramos um artigo intitulado "Violas". Em apenas cinco páginas, Luiz Heitor apresenta os diferentes sistemas de afinações do instrumento em diferentes locais do Brasil. A partir de breve consideração sobre as supostas origens da viola, seu formato, tipos de encordoamento e distintas nomenclaturas para as cordas e demais partes, ele apresenta as variadas afinações do instrumento: "paulista", "guitarra", "oitavada ou rio abaixo", "serra abaixo" e maxambomba. Esses são alguns nomes para designar as afinações transcritas com o auxílio de uma pauta musical. Nomeando cada corda a partir de seu respectivo som (nota musical), o musicólogo, quando menciona, por exemplo, a afinação "guitarra", expõe a respectiva relação entre as notas (ré/si/sol/dó/sol), partindo das cordas de baixo para cima (da corda mais aguda para a mais grave). Já quando se refere à afinação "rio abaixo" (ou "oitavada"), a relação entre as notas passa a ser ré/ si/sol/ré/sol e assim por diante.

Ao aproximarmos Hornbostel e Luiz Heitor, só para mencionarmos duas figuras importantes da pesquisa musicológica em diferentes latitudes, notamos que para ambos a afinação foi assunto de análise e descrição. Salvo as diferenciações nas respectivas abordagens que não cabe aqui aprofundar, um mesmo procedimento é posto em prática: as afinações dos instrumentos são concebidas como estruturas estáveis de distâncias entre grupos de notas relacionadas entre si. Como bem recordou Oliveira Pinto (2001), e que vale para os dois casos aqui brevemente recuperados, o tema da afinação costumava ser tratado a partir de um modelo fixo, mensurável e traduzível para a terminologia ocidental.

Diferentemente dos usos e significados da categoria afinação (como produto), no contexto dos giros rituais das folias, afinação é um verbo, uma ação, um afinar, portanto. Prática coletiva e eficaz, em virtude de sua realização coisas acontecem. Desde esse enquadramento, a questão torna-se mais complexa: Quais são os mundos criados nos giros? Como a afinação produz contextos ("enquadramentos") e como nela ocorre a transformação do campo perceptivo, cognitivo e interpretativo dos participantes?

Para dar conta dessas questões, também precisamos afinar nossa perspectiva com outras referências. É o que pretendo fazer aqui, expondo alguns possíveis caminhos 
teórico-metodológicos. A primeira referência nessa direção é Alfred Schutz, em um artigo intitulado "Making music together: a study in social relationship" (1976 [1951]). Schutz mobiliza sua sociologia fenomenológica para compreender as formas de comunicação humana, em especial a que ressoa na prática (no fazer) musical. Focalizando o fenômeno de tocar junto, principalmente em grupos reduzidos, sem a presença de lideranças e hierarquias explícitas (como é o caso de uma orquestra regida por um maestro), ele procura descrever e analisar os elementos estruturais característicos do processo de comunicação envolvidos nesse fazer.

Conduzida pelas interações face a face, por meio do envolvimento e engajamento dos participantes, fazer música em conjunto, para Schutz, implica um modo de relacionamento que depende do compartilhamento do tempo (ou da duração) e da coabitação no espaço. Nesse ambiente, o processo musical acontece na e pela busca de uma "sintonia mútua no relacionamento" (mutual tuning-in relationship no original), movimento em que o "eu" e o "tu" cedem lugar à experiência de um "nós". Para Schutz, esse é o fundamento de toda comunicação possível.

Ainda de acordo com Schutz, esse modo de relacionamento, presente de igual modo em outras práticas (na "marcha", no "amor", na "dança"), envolve ações realizadas em parceria com outras pessoas por meio de interações concretas, da coordenação mútua de movimentos e da busca de uma sintonização a ser criada e vivenciada no curso (e no fluxo) das situações. Nesse regime comunicacional, um músico (um amante ou um dançarino) não somente deve ouvir o outro, mas também vê-lo e senti-lo. Sua ação é afetada pelo que o parceiro faz:

The Other's facial expressions, his gestures in handling his instrument, in short all activities of performing, gear into the outer world and can be grasped by the partner in immediacy. Even if performed without communicative intent, these activities are interpreted by him as indications of the what the Other is going to do and therefore as suggestions or even commands for his own behavior. Any chamber musician knows how disturbing an arrangement that prevents the coperformers from seeing each other can be (1976 [1951]:176).

As elaborações de Schutz apresentam insights interessantes para pensarmos a afinação nas folias. Primeiro, a ideia de que a prática musical envolve a criação de uma sintonia mútua entre as pessoas e que tal acordo é construído em interações concretas. Quando dizem que estão acertando seus instrumentos, os foliões se engajam em uma prática coletiva e relacional que ocorre na temporalidade e no fluxo contínuo das interações face a face. O compartilhamento das percepções na simultaneidade da duração e na coabitação do espaço no processo de afinação têm como objetivo, como dizem, reunir, aproximá-los física e emocionalmente, juntá-los e envolvê-los em uma experiência única e compartilhada. 
Outro aspecto que Schutz evidencia também muito importante na afinação diz respeito ao fazer musical e à produção da "sintonia mútua no relacionamento". A afinação não envolve somente sons e o compartilhamento de uma mesma temporalidade, mas engloba vários outros sentidos. Como veremos ao longo da descrição etnográfica, quando estão afinando, os foliões se comunicam por meio de sons, gestos, palavras, expressões faciais, olhares, movimentos e no engajamento corporal com suas violas, violões, rabecas e caixas. Nesse sentido, quando acertam os instrumentos, acionam percepções temporais e espaciais diversas.

A sintonia criada no fluxo das interações mediante a mobilização e combinação de um conjunto de elementos expressivos (sons, gestos, objetos, palavras, expressões, olhares), ao intensificar a experiência de coletividade ("nós"), parece produzir uma "orquestração interpessoal" ou "integração social" (Tambiah, 1979). Nessa direção, o entrelaçamento dos múltiplos meios comunicacionais e expressivos somados à espacialidade, temporalidade e corporalidade do processo de afinação funcionam como "demarcadores" ("contextual cues", segundo Bauman e Briggs, 1990). São "mecanismos de focalização" (Tambiah, op.cit) que informam que algo está acontecendo, ou melhor, que fazem algo acontecer naquela situação" ${ }^{11}$.

Percebe-se que, durante a afinação, há uma mudança na qualidade das relações, no comportamento, atitude e padrão emocional dos participantes - da descontração e dispersão inicial quando se chega à casa e se cumprimenta os moradores para uma postura de maior concentração, seriedade e solenidade. De acordo com Bateson (2000 [1955]), podemos dizer que um dos efeitos da afinação é criar um "contexto interpretativo" (ou "enquadramento") capaz de fornecer aos sujeitos, no curso das interações, elementos (sinais ou demarcadores) para compreenderem e vivenciarem aquela situação.

Assim, durante a afinação, a atenção e percepção são direcionadas para o que está acontecendo e ao engajamento com (na) atividade. Os participantes se deparam com os elementos básicos para identificar a situação e responder à pergunta: "O que está acontecendo? O que se passa?". Goffman (1974), em um desdobramento das reflexões de Bateson, diz que o principal objetivo no estudo das frames é percebê-las enquanto transformações, e não como estados fixos. Dessa forma, o interesse recai menos na "moldura" ou "enquadramento" propriamente dito, e mais no processo de produzi-los (no ato de "enquadrar" e "emoldurar", portanto). Para tanto, Goffman propõe que o estudo sobre frames focalize as "claves" ou "chaves" (keys no original), pois é por meio delas que as situações são enquadradas. Indo mais além, diz que o conceito central para se interpretar como se criam e se transformam frames é o de keying. A categoria sinaliza, por um lado, que estamos diante de processos transformacionais e, por outro, que as transformações pressupõem acordos e consensos ${ }^{12}$.

Outra dimensão das frames que dialoga com o fenômeno da afinação é seu caráter metacomunicativo (Bateson, op. cit). Tendo como assunto do discurso a própria "relação entre os falantes", essa comunicação sobre a comunicação (ou metacomunicação) é o
11 | Para Tambiah, o significado da comunicação em contextos rituais não se dá somente (e nem fundamentalmente) em termos referencias e informacionais (o que está sendo transmitido e qual o sentido do que é dito na relação com algo a que se refere), mas em termos performativos, em sua capacidade de produzir engajamento entre os participantes. Nas palavras do autor: "Social communication of which ritual is an especial kind, portrays many features that have little to do with the transmission of new information and everything to do with interpersonal orchestration and with social integration and continuity. The orchestration and integration aspects of communicative process (Birdwhistell, 1970: 86-7) includes many operation: the 'phatic' feature which keeps the communication system in operation, the certainty of message that eases an interpersonal anxiety and affective lesion, the battery of linguistic and other cues which act as triggering mechanisms and context markers, the regulative etiquette that orders what is considered as proper communication in equal or asymmetrical statusestheses are a related set" (1979: 132-133. Grifos meus).

$\mathbf{1 2}$ | Interessante perceber que um dos significados do verbo "to key" (ou "keying") tem como possíveis sinônimos "to attune" ou "to tune", que traduzido para o português significa justamente "sintonizar" e "afinar". 
que permite aos participantes distinguirem, por exemplo, quando um mesmo ato deve ser interpretado como uma luta ou como uma brincadeira de luta ${ }^{13}$. A mesma dimensão parece estar presente na afinação, quando a própria qualidade da relação entre os músicos e os demais participantes fica em evidência. Ao salientar que a natureza das relações deve ser interpretada de um modo específico e distinto do que vinha sendo, o afinar pode ser compreendido como um modo de comunicação que versa sobre as potencialidades da própria comunicação.

Desse modo, a afinação é em si um ato eficaz, já que a partir dela e nela interações e significados emergem. De igual modo, o ato de afinar traz consigo, como em uma cadeia sintagmática, eventos e situações que o antecede e o sucede. Assim, para entendermos o que dele emerge, é interessante situarmos a afinação no fluxo do processo ritual. Assim, por mais que eu me volte para a descrição etnográfica da afinação (do afinar) em primeiro plano, devemos lembrar que ela integra uma sequência mais ampla de acontecimentos (um antes e um depois): de um lado, a caminhada dos foliões bem como os cumprimentos e saudações entre eles e os moradores na chegada da casa e de outro, a cantoria já no interior da moradia.

Como uma teia, o ato de afinar articula uma passagem, uma abertura, um importante elo que veicula e entrelaça diferentes fases e sequências rituais. Ao lado da dimensão processual e transicional, o afinar, enquanto situação liminar, revela ainda a precariedade, ambiguidade, incerteza e perigos que rondam os seres e as condições indeterminadas, situadas nos interstícios entre as posições mais estáveis e permanentes (Turner, 2005 [1964]; 2013 [1969]). Como veremos, a afinação em sua incessante busca por estabilização, equilíbrio, consenso e coesão está, a todo momento, sendo posta à prova e correndo riscos de não ser bem-sucedida. A esse respeito, vale recuperar o seguinte comentário de Wisnik:

Nos rituais que constituem as práticas da música modal invoca-se o universo para que seja cosmos e não caos. Mas de todo o modo, os sons afinados pela cultura, que fazem a música, estarão sempre dialogando com o ruído, a instabilidade, a dissonância. Aliás, uma das grandes graças da música é justamente essa: juntar, num tecido muito fino e intrincado, padrões de recorrência e constância com acidentes que os desequilibram e instabilizam (1989: 27).

Partindo da ideia de que a afinação é um evento performativo e eficaz, produtor de frames e "enquadramentos", a proposta agora passa a ser a descrição e análise dos contextos e dos fluxos das interações. Afinal, quais são os meios comunicacionais e como se combinam para produzir a experiência de coletividade? Que sinais e elementos (sons, gestos, palavras, objetos) são mobilizados (e como são mobilizados) para gerar a "sintonia mútua no relacionamento" (Schutz, 1951)? Como a "orquestração interpessoal" (Tambiah, 1979) necessária para o "enquadramento" perceptivo e interpretativo conduz 
ao canto? Em que consiste esse aparente consenso e como ele pode (e é) ameaçado? Como os ruídos, as instabilidades e dissonâncias incidem na afinação?

\section{SANTOS E FOLIAS}

$\mathrm{Na}$ Taboquinha, o conjunto instrumental das folias é formado por violas, violões, rabeca e caixa, além de pandeiros, do balainho e da geroma ${ }^{14}$. A preponderância dos instrumentos de corda nessas folias justifica, como vimos no prelúdio deste artigo, o termo "cordial" para nomeá-las. Os instrumentos, embora possam ser reunidos e percebidos em conjunto, se diferenciam entre si tanto do ponto de vista da sonoridade e narrativa de origem quanto do uso e significado nos contextos rituais.

Muitos devotos dos Reis Magos - a cada ano, entre 24 de dezembro e 6 de janeiro - participam das festividades e folias dedicadas aos Santos Reis. Para os devotos, os Três Reis eram, além de pessoas de grande sabedoria e intuição, músicos (tocadores e cantadores) habilidosos. Em diversos relatos sobre as origens das folias de reis, menciona-se o fato dos magos levarem para a viagem e visita ao Menino Deus recémnascido, instrumentos musicais. Os mais citados são a viola, caixa e rabeca (e em alguns casos o pandeiro) ${ }^{15}$, além, claro, dos conhecidos presentes - incenso, ouro e mirra.

No correr de um giro de folia na Taboquinha, quando observamos os comportamentos e o modo como as pessoas se relacionam com os instrumentos, a centralidade da viola é nitidamente percebida. Ela é o instrumento mais apropriado para uso do guia ou cabeça ${ }^{16}$, além de ser, como veremos adiante, a base para o processo de afinação. Ao lado da viola, como indicam as narrativas, a rabeca, o pandeiro e a caixa também são imprescindíveis - justamente por estarem associados aos reis magos e à folia original.

Quanto aos demais instrumentos, podem ou não estar presentes. Chamo atenção particularmente à geroma e ao balainho, pois são os que mais circulam por diferentes mãos. É comum durante um giro ver esses instrumentos passando de mão em mão, diferente da viola e da rabeca, por exemplo, que normalmente permanecem todo o tempo com o mesmo (ou com poucos) tocador. Certa vez ouvi um comentário que justificava a circulação da geroma e do balainho, argumentando que eram instrumentos "que não tem ciência". Achei o comentário curioso e intrigante: mas por que esses instrumentos não têm ciência? Por que alguns instrumentos têm ciência e outros não? Tendo em vista a não participação deles no processo de afinação, será que o termo ciência é relacionado com as cordas e, por conseguinte, com a afinação? Curiosamente, como veremos, os instrumentos que têm ciência (os de corda, incluindo a caixa, e, no limite, a voz) são os alvos preferenciais das práticas de magia e feitiços (malinagens e atrapalhos) que podem perturbar o bom andamento de uma folia incidindo justamente em suas afinações.

14 | Obalainho é um tipo de chocalho. Consiste em uma pequena cesta de palha, cujo interior contém sementes - quando movimentadas produzem som. Já a geroma, também é um tipo de chocalho, mas é feita de um pequeno aparato de madeira com um cabo e uma estrutura retangular vazada (semelhante a uma raquete) Essa é atravessada por fios de arame nos quais se colocam tampinhas que quando percutidas produzem som.

15| Desses três (ou quatro) instrumentos que aparecem nas narrativas de origem da folia, a viola é particularmente ambígua. Além de sacralizada por ser um dos instrumentos dos reis magos, em muitos relatos, aparece como o instrumento do diabo, considerado por muitos tocadores um exímio violeiro dotado de uma habilidade inigualável para tocar e tirar som do instrumento (Chaves, 2020). Para uma análise comparativa de um conjunto de relatos acerca das origens da folia, ver Chaves (2014b).

16 | Cabeça (ou guia) é o termo que nomeia a principal liderança dos grupos de folia, aquele que detém os conhecimentos dos preceitos rituais, que domina o repertório de cantos e conduz as performances nas mais diferentes situações. 
$\mathrm{Na}$ Taboquinha, como já mencionei, existe uma grande diversidade de folias ao longo do ano, configurando um vivo e intrincado calendário de giros e festividades dedicadas a diferentes santos do panteão católico. Quando observamos esse conjunto de folias, uma importante distinção deve ser sublinhada - a que separa e distingue a folias de reis das demais (chamadas folias de bandeira). A de reis, considerada a primeira e principal folia, é a única que realiza o giro sem a bandeira e à noite, tal como fizeram os três reis. Vale lembrar que, de acordo com o relato bíblico e como enfatizam os foliões em suas narrativas, os magos caminharam à noite e foram guiados pelo brilho de uma estrela. Na ótica dos foliões, se os reis foram perseguidos por Herodes, eles também estão sendo perseguidos. Nessa lógica, andar à noite diminui os riscos, sempre presentes, de se depararem com situações indesejáveis. O silêncio é outro valor capital na organização dos giros dessas folias, como esclarece o saudoso folião Joaquim Goiabeira na passagem abaixo:

A folia mais sincera do mundo é a folia de reis, ela é à noite, anda à noite todinha e é uma folia que é assim: é caladinha, se tem que cantar aqui, ali, para todo mundo, acerta os instrumentos, e vem, já os quatro cantador já entra um atrás do outro, no silêncio, os tocador já sabe, vem pisando em silêncio, chega, a porta tá serrada, você empurra ela bem devagarzinho, aí entra, quando começa a cantar que o dono acorda ... (Depoimento de Joaquim Coiabeira. Grifos meus).

Como diz o folião, que em vida foi um exímio construtor e tocador de caixa, na folia de reis, o silêncio é fundamental ${ }^{17}$. Além de enfatizar a singularidade da folia de reis, que anda somente à noite (à noite todinha), ele nos explica como ocorre a afinação. O processo de afinar (ou acertar) os instrumentos nesses casos tem início quando os foliões, que até então vinham caminhando, param e se reúnem nas proximidades da casa a ser visitada. A distância deve ser suficiente para que o som dos instrumentos não seja ouvido da moradia. Seguindo o relato de Joaquim, após terminado o processo de afinação, quando os instrumentos já estão acertados, os foliões, em silêncio ("pisando em silêncio") caminham até a casa adentrando em seu interior para só então, posicionados na sala e no escuro, iniciarem o canto.

Bem diferente é o que acontece nas folias de bandeira, termo usado para se referir às folias, exceto a de reis. Nessas folias não se observa a mesma preocupação com o silêncio característico das folias de reis. A caminhada e chegada nas casas são envoltas em uma atmosfera de maior descontração e informalidade. Os giros são realizados durante o dia e com a presença da bandeira-um estandarte com a imagem do santo que sempre permanece à frente do grupo. É a bandeira que anuncia os foliões nas caminhadas, chegadas e saídas de casas. A dinâmica do afinar e chegar às casas

17| O valor e a centralidade do silêncio nas folias de reis chamaram a atenção de pesquisadores como Carlos Brandão que, em seus estudos junto às folias de Caldas, Minas Cerais, fez a seguinte observação: "Dizem velhos foliões de Caldas que, no passado deles meninos, a jornada se cumpria com muito maior rigor e com muito mais obediência ao que se supõem que faziam os Três Reis a caminho de Belém. Perseguidos pelas forças de Herodes, eles viajavam só durante à noite, em silêncio pelas estradas. Chegando em uma casa pediam pouso, sem cantar e com pouco alarde. Apenas dentro da casa cantavam. Durante o dia ficavam dentro de um pouso para saírem de novo ao escurecer de um novo dia em mais uma noite inteira de jornada. Escutei as mesmas notícias em outras folias de Minas e Goiás (Brandão 1981:52). Se a caminhada à noite e o silêncio, em Caldas e também em Mossâmedes, Goiás (Brandão, 1977:10), eram lembranças de jornadas passadas, na Taboquinha são práticas que organizam os giros nos dias de hoje e demarcam a singularidade das folias de reis em relação às demais folias. 
também é distinta nesses casos. Grosso modo, podemos descrevê-la em seis etapas sucessivas:

1) afinação nas proximidades da casa, como na folia de reis, porém sem o cuidado para que o som não seja ouvido pelos moradores;

2) caminhada até a porteira que delimita a propriedade;

3) início da alvorada (tema instrumental) - executada entre a porteira e a porta que dá acesso ao interior da casa;

4) na sala da casa, saudações e cumprimentos entre os foliões e os moradores;

5) ainda na sala, nova afinação (agora mais demorada e atenciosa quando comparada com a que foi realizada anteriormente);

6) canto dedicado a anunciar a presença do santo, agradecer as ofertas, distribuir bênçãos aos moradores e convidá-los para a festa de encerramento do giro.

Tendo feito esses comentários gerais sobre a diversidade de folias, a organização instrumental e os contextos em que acontece o processo de afinação, passo à descrição etnográfica da dinâmica de uma situação específica por mim vivenciada durante o giro da folia de São José no ano de 2006. Trata-se da chegada da folia na casa de um senhor conhecido como Zé Podaça. A descrição que se segue é conduzida pela escuta da gravação que realizei na ocasião. Nesse exercício de escuta e escrita, o som das falas, dos instrumentos e os silêncios serão os guias para a narrativa etnográfica ${ }^{18}$.

\section{CHEGADAS, SAUDAÇÕES E BRINCADEIRAS}

Taboquinha, 18 de março de 2006, véspera do dia de São José. A folia de São José se aproxima da casa de seu Zé Podaça, na ocasião um senhor de quase 80 anos que por muito tempo integrou, como folião, o terno de folia da localidade. Após acertarem os instrumentos nas proximidades da porteira que dá acesso à propriedade de seu Zé, os foliões se preparam para iniciar a alvorada. É com o som instrumental da alvorada e com a bandeira à frente do grupo que eles atravessam a porteira e percorrem o espaço que a separa da porta de entrada da casa. Seu Zé, assim que percebe o movimento dos foliões na entrada de sua propriedade, se direciona para a porta e de lá observa e escuta a chegada da folia em sua moradia. À medida em que os foliões se aproximam da porta de entrada da sala, seu Zé se adianta e adentra o salão, para onde se dirigem os tocadores enquanto executam a alvorada, que só se encerra no momento em que todos - foliões e donos da casa - se encontram nesse espaço.

Assim que cessa a alvorada, tem início uma série de interações verbais entre o morador e os foliões. São fórmulas de saudação e cumprimentos amistosos e descontraídos comuns quando as pessoas se visitam. Alguém se dirige a seu Zé e pergunta "O senhor tá bom?"; ao que ele responde "Tô bem graças a Deus!". Outro folião reforça "Cê tá bom mesmo?" e, em seguida, se dirigindo novamente ao dono da casa pede "Bênça!?". Prontamente seu Zé retribui com “Deus te abençoe!". Outro

18 | Além de me basear na escuta do registro sonoro realizado nessa situação específica, minha descrição ainda se apoia em mais dois planos complementares: primeiro, me valendo da observação e vivência de inúmeros casos similares, a narrativa se desprende dessa situação específica para apresentar o que poderia ser concebido como um padrão recorrente de visitas; segundo, a descrição da situação concreta, bem como o modelo abstrato, será complementado com explicações, exegeses e elaborações dos próprios foliões acerca do processo de afinação. Nessa direção, a presente descrição movimenta simultaneamente os três planos da perspectiva etnográfica como formulada na célebre introdução de Malinowski (1922) aos

"Argonautas do pacífico ocidental", a saber: 1) os "imponderáveis da vida real" (carne e sangue), que é o modo como as pessoas agem, se comportam e se relacionam nas situações concretas; 2) O esquema ("esqueleto"), abstração construída pelo pesquisador a partir da observação do maior número possível de casos concretos; 3) O "espírito", relacionado às elaborações e exegeses dos nativos sobre determinado assunto. 
folião chega e pergunta em tom de brincadeira "Firme e forte?". Seu Zé, fazendo graça, arremata "E bonito também!". Nesse momento risos tomam conta do ambiente. Seu Zé, ainda em tom jocoso, a mim se dirige e fala alto para que todos ouçam: "Olha São José" (risos) "Ói São José ... graças a Deus!"19 mais risos. Por fim, seu Martinho, folião da mesma geração que seu Zé, dirige-se a ele com as palavras "Como vai cumpadi?" e ouve a resposta "Eu tô bem, e você cumpadi?".

Nesse momento de chegada, as falas são altas, às vezes simultâneas e sobrepostas, criando uma atmosfera agonística de excitação e brincadeira. Como diria Malinowski (1972 [1930]), mais do que comunicar ou informar, esse tipo de troca comunicativa tem como propósito aproximar as pessoas, produzir sociabilidade, engendrar um ambiente de confraternização, congregação e amizade. Em tal regime comunicacional, a troca de palavras sem um necessário significado referencial ou semântico, visa estabelecer e prolongar relações, gerando o que se chama de "comunhão pática". Nas palavras de Malinowski, trata-se de "um tipo de fala em que os laços de união são criados pela mera troca de palavras"2o.

Com uma forte inclinação para estabelecer e manter o contato amistoso entre os participantes - os foliões e os moradores que os recebem - essas falas também demarcam (e criam) determinadas relações e posições sociais (Tambiah,1979). Nessa direção, as fórmulas de saudação podem ser entendidas como ritos que afirmam o status em duas direções:

* Verticalmente: os pedidos e distribuição de bênção entre foliões e o dono da casa expressam e criam assimetrias, legitimando a autoridade dos mais velhos sobre os mais novos;

* Horizontalmente: os cumprimentos também revelam e criam relações de igualdade e simetria. Isso pode ser observado quando dois compadres se encontram e se reconhecem.

De um modo ou de outro, o que se percebe nesses ritos de chegada e saudação, ainda que com pequenas variações a cada nova visita, é o modo como as hierarquias e relações das posições sociais estão longe de serem abstrações ou realidades préexistentes. Pelo contrário, são criadas durante atividades concretas e no curso das ações e interações ${ }^{21}$.

\section{ALTURAS, FREQUÊNCIAS E SINTONIAS}

Ao longo da escuta da gravação, é perceptível como os risos e as falas vão diminuindo de intensidade à medida em que o som dos instrumentos é amplificado, soando e ressoando no ambiente, criando assim um "espaço acústico" (Schafer, 1997 [1977]) singular. Ao lado dos sons, gestos como a retirada dos chapéus e a movimentação corporal dos foliões evidenciam (e geram) a transformação em curso. A busca do limiar sonoro (termo que uso para me referir ao movimento em direção ao som afinado,
19| Em determinado momento desse giro, seu Zé, que eu pouco conhecia até então, começou a brincar comigo dizendo que eu era parecido com São José. Quando a folia chegou a sua casa, seguindo a etiqueta para essas ocasiões, fui cumprimentá-lo assim como fizeram os demais. O que eu não esperava é que ele, em tom de brincadeira e falando alto para que todos o escutassem, agradecesse a Deus por São José estar entre eles. Para além de alguma possível semelhança com a imagem de São José, a associação de um (relativo) estranho e desconhecido com o sagrado e misterioso foi apontada por Pitt-Rivers (2012) em um interessante estudo sobre as leis, regras e etiquetas da hospitalidade. Entre outras considerações, ele mostra como nas relações entre anfitriões e estrangeiros, os últimos, em tese, representam perigos e ameaças e, no limite, poderiam ser tratados com hostilidade e ofensa. Mas também se transformam em hóspedes e visitantes, com quem o hospedeiro passa a manter relações amistosas de troca e reciprocidade. Essas relações, todavia, não impedem que as diferenciações entre os respectivos papeis (quem recebe e quem chega) sejam eliminadas.

20| Malinoswki (op.cit) diz que romper o silêncio com frases como a europeia "Faz hoje um belo dia" ou a melanésia "Donde vens?" é o primeiro ato no intercurso de uma relação cujo propósito principal é estabelecer. entre os participantes, laços de amizade e troca (não de hostilidade, animosidade ou guerra). O pendor para o contato intrínseco nesse tipo de interação é, para Jakobson, um exemplo da chamada

"função fática" (1973 [1960]), que, segundo ele, é para "verificar se o canal funciona". Van Cennep (2011 [1908]), em seu estudo pioneiro sobre os ritos de passagem, já havia sinalizado que as "saudações" são importantes ritos de passagem, já que promovem aos que chegam agregação e, portanto, aceitação e incorporação ao novo ambiente.

21 | Desse modo é que, seguindo Bauman (1977), podemos dizer que tais ritos são contingentes (pois são construídos nas interações 
acertado) envolve múltiplas interações e mediações (Hennion, 2003; 2011) - movimentos corporais, expressões faciais, posturas, olhares, palavras, vozes, instrumentos musicais, sonoridades, entre outros.

Tal movimentação de coisas, sons e pessoas cresce paulatinamente até alcançar o clímax, quando todos tocam juntos um mesmo acorde. Nessa hora, as sonoridades dos instrumentos se sobrepõem e se fundem em uma mesma frequência (altura), originando um padrão sonoro constante e sintonizado com os valores estéticos e morais dos foliões. Quando esse limiar é alcançado e reconhecido, todos permanecem, por alguns segundos, em silêncio até que o guia entoa em sua viola os primeiros acordes do canto.

A altura de referência para afinação é fornecida pela segunda corda da viola (de cima para baixo, do grave para o agudo), chamada baixão $0^{22}$. As outras cordas da viola, rabeca e violão são afinadas em função do baixão e a caixa, instrumento mais vulnerável às variações, é sempre o último. Como me esclareceu o finado Neudir, um dos foliões que assumia o comando do processo:

Eu pego pela segunda corda. A viola é melhor pra dar o som pros outros. A caixa é a derradeira, até o tempo regula ela. De repente o sol tá quente e tá lá fora, ela vai tá alteando, você baixa ela, quando você entra já alteou de novo.

A altura da afinação da segunda corda da viola, ou baixão (estejamos atentos a esse termo), é a referência para as demais cordas e indicadora do som para os outros instrumentos. É ela que fornece a base sonora do conjunto. Todavia, o baixão da viola deve ser acertado em função da voz de quem canta. Os violeiros e demais tocadores afinam seus instrumentos de acordo com a altura das vozes de quem vai cantar. $A$ altura da afinação deve ser, em última instância, boa para cantar.

A referência para o processo de afinação nas folias, desse modo, é a altura. Relacionando alto e baixo, a afinação é sempre um movimento em direção a estabilização e ordenamento sonoros. A altura está sempre sendo construída na relação entre sons e na busca de padrões de recorrência, sempre provisórios, entre o mais baixo e o mais alto. Durante o afinar, é comum ouvir enunciados como: "O seu baixão está por cima."; "Alteia aí um tiquinho a toeira."; "Aperta mais a caixa."; "Tá faltando."; "Ainda tem uma diferençazinha."; "Aí, agora sim!". São os ouvidos, a percepção do que se ouve, os gestos, os movimentos corporais, olhares e expressões faciais que conduzem o processo.

Como explica novamente Neudir:

A gente acerta, né? Porque muitas vezes a pessoa tá com aquele instrumento que não tá afinado, aí toca naquela alturona, pode fazer as notas certa, mas fica assim tipo roubar o som dos outros. Aí, por exemplo, você tá do lado; aí, você descobre; aí, eu pego e chego neles e falo. concretas situadas no tempo e no espaço) e emergentes (em virtude de coisas acontecerem durante sua realização, relações são produzidas e transformadas).

$\mathbf{2 2}$ | A viola, do ponto de vista do citado sistema organológico de Sachs e Hornbostel [1961] (1914), é um cordofone de dez cordas, distribuídas em cinco ordens de cordas duplas. $\mathrm{Na}$ Taboquinha, as cordas da viola são enumeradas em ordens de pares de cima para baixo (seguindo a classificação do folião Neudir). São elas: bordão, baixão, retinta e baixim, toeira, prima. Os pares de cordas são afinados em uníssono, como é o caso das quarta e quinta ordens, respectivamente, ou em oitavas, como é o caso da primeira, segunda e terceira ordens. No caso das duas primeiras, as cordas de menor calibre, mais finas, oitavadas, são chamadas de companheiras, do baixão ou do bordão. No caso da terceira ordem, cada corda recebe um nome, sendo a retinta a mais grave e baixim a mais aguda. Para uma descrição mais detalhada da viola e demais instrumentos musicais usados nas folias, ver: Chaves e Fonseca (2005). 
Movimento em direção a um limiar sonoro, a afinação gera uma tessitura de sons que procuram se estabilizar em um ponto definido. $\mathrm{O}$ objetivo do processo, como esclarece o folião, é colocar todos os instrumentos em uma mesma altura (ou frequência) para nenhum roubar o som do outro. Essa metáfora é reveladora de um ideal que valoriza o conjunto (no sentido de coletividade), cuja existência depende de como cada instrumento individualmente contribui e se integra na totalidade. Nesse sentido, um instrumento, para se acertar com o outro, deve vibrar na mesma frequência (e não soar por cima nem por baixo) ${ }^{23}$.

A sintonização (Schutz, [1951] 1976), construída na dinâmica de equilíbrio entre tensões, frequências e alturas, é manifestada no acorde final, quando todos tocam em uníssono. Nessa hora, as diferenças são minimizadas, as incertezas ordenadas e as dissonâncias controladas. A afinação, nessa ótica, é um processo de busca pela altura ideal (nem baixa demais nem alta) para o canto, criando, assim, um contexto favorável para execução. Altura essa que tem como referência o registro vocal do cantador e, com guias, os ouvidos dos foliões.

Logo, o primeiro passo da afinação é a definição da altura correspondente ao som do baixão da viola. Com a referência do som do baixão da viola, cada tocador pode então acertar o próprio instrumento. Definida a altura, o enfoque passa a estar na relação das demais cordas do instrumento com o vínculo entre a voz do cantador e o baixão. Desse modo, o folião, antes de conferir a afinação com os outros, deve acertar sozinho seu instrumento. Note-se bem que, independentemente da nota do baixão (dó, ré ou sol), o que importa é a relação entre seu som e o som das outras cordas. É esse movimento que orienta o afinar. Sonoro, visual e corporal, o processo exige do tocador, além de uma apurada percepção auditiva, uma atenção ao outro (seus gestos, expressões e atitudes). Podemos dizer então que o corpo todo (e todos os sentidos) participa da afinação ${ }^{24}$.

Definido o som do baixão, o trabalho passa a ser ajustar todas as cordas a partir desse eixo. A afinação se dá em um contínuo sonoro (de alturas, frequências e tensões). Mais do que designar estados fixos, a referência à altura dos sons aponta para relações que são percebidas sensorialmente por ouvidos sempre atentos. Relações que, ao buscarem um limiar neste universo de possibilidades e nesse movimento contínuo de sons e alturas (do mais alto ao mais baixo), nos trazem à lembrança as reflexões de Lévi-Strauss sobre o cromatismo (2004 [1964]) 25 .

Engajar-se na afinação, portanto, implica dois movimentos:

1) Um trabalho individual do músico junto a seu instrumento, afinal, em última instância, cada um é responsável por acertar o próprio instrumento. Esta é a condição para tocá-lo na folia, ainda que o processo seja iniciado com o som fornecido pela viola do mais apto a orientar o processo. Desse modo, não é incomum ver os foliões, após obterem o som guia, se deslocando com seus instrumentos para sozinhos, ou mesmo em duplas, acertá-los.
23| O termo "frequência" está sendo por mim utilizado no sentido apontado por estudiosos da acústica musical tais como Everest \& Pohlmann (2009). De acordo como eles, a "frequência" de um som se refere tanto à propriedade de como a onda sonora se propaga no ambiente (uma propriedade física, portanto) quanto ao modo como é percebida pelos ouvidos humanos (um fenômeno psico-acústico). Como sublinham, a especificidade de uma frequência é aferida pela quantidade de repetições ou ciclos da onda sonora em uma dada unidade de tempo (geralmente medida por segundo): quanto mais repetições, mais altas e

agudas são as frequências e vice e versa (menos ciclos por segundo significa sons em frequências mais baixas e graves). Embora não se possa igualar frequência e altura, já que outros aspectos devem ser levados em conta, tais como intensidade e timbre, os dois fenômenos, como fazem questão de sublinhar, são análogos e é nesse sentido que utilizo os termos neste artigo. Como estamos vendo, durante a afinação, o esforço dos foliões é direcionado para estabilizar as distintas frequências

(perceptível constante deslizar entre sons graves e agudos) em um mesmo padrão de altura (nem tão acima nem tão abaixo). Afinar assim, como argumento, é um movimento, uma busca em direção a uma frequência (altura) constante, regular e ordenada.

24 | Schutz evidencia que a sintonia relacional mútua implicada no fazer musical envolve, além do compartilhamento do tempo a coabitação em um mesmo espaço. O que leva um músico a não somente ouvir o outro, mas também a vê-lo e a agir levando em conta o que o outro executa (seu movimento) no tempo e no espaço. Nas palavras do autor, o ambiente de co-presença (espaçotemporal): "é possível porque fazer música juntos ocorre em um verdadeiro relacionamento face-a-face - na medida em que os participantes estão compartilhando não apenas uma seção de tempo, mas também um setor do espaço" ([1951] 1976:176). Baily e Driver, em um interessante estudo sobre a guitarra no blues, dizem que o componente central da cognição musical não deve ser buscado nos aspectos ergonômicos (que se relaciona com as capacidades 
2) Uma vez finalizada a afinação de cada instrumento separadamente, os foliões se reúnem novamente e ajustam juntos a sonoridade dos seus instrumentos. Do ponto de vista temporal, podemos dizer que a afinação movimenta (e se movimenta em) duas temporalidades: em um primeiro momento, após definida altura do baixão, ela acontece corda a corda, passo-a-passo, sucessivamente, estendendose cronologicamente ao longo da linha temporal. Nesse plano, os foliões vivenciam individualmente e/ou em duplas, na diacronia, a sequência dos atos que fazem da afinação um fenômeno mensurável, situado no que Schutz denomina "outer time"26. Já em uma segunda fase, a afinação se move verticalmente e sincronicamente (na simultaneidade), no tempo vivido (que não coincide com o tempo mensurável), no que Schutz, inspirado em Bergson, chama de duração (ou "inner time"). Essa vivência é expressa quando todos, partindo de um mesmo som (o baixão) e após terem acertado seus instrumentos, tocam juntos e simultaneamente um mesmo acorde. O canto, momento de maior sacralidade de uma visita, não se inicia sem que esse limiar seja alcançado ${ }^{27}$.

Tendo apresentado o processo de afinação, voltemos à categoria baixão que, como vimos, é usada para nomear uma corda específica da viola, aquela que fornece a base para a afinação. Ao acompanharmos outros usos desse mesmo termo, ainda no contexto da folia, percebe-se que baixão também alude a uma figura sonora presente no canto e que representa o prolongamento da última sílaba ao final de um par de versos. Nesses contextos, o termo baixão se refere ao longo "pedal" que demarca sonoramente a passagem entre a pergunta e a resposta (ou vice e versa) e que coincide com a passagem entre as performances das duas duplas de cantadores. O ponto é que tal limiar envolve um entrelaçamento de vozes, em um dado momento (por mais efêmero que seja), que soa como um único e indiviso som (Chaves, 2014a).

Comparando os usos do termo baixão nas duas situações (afinação e canto), percebe-se que em ambos os contextos a categoria apresenta um mesmo sentido geral - a busca por uma experiência de continuidade, coerência, ordenamento e estabilidade. A própria análise do significado do termo, que acopla o sufixo aumentativo "ão" ao adjetivo baixo (baixo grande), demonstra o som grave, grosso ou pesado que remete à sustentação e à base da produção sonora. O valor que o som grave tem na perspectiva dos foliões pode ser notado também na dupla de cantadores - o guia é aquele que canta no registro mais grave. Vale lembrar que, em sentido inverso, o diminutivo "inho" é acoplado ao substantivo gerando o termo baixi ou baixo pequeno - termo que nomeia outra corda da viola.

Schafer, no mencionado estudo sobre "paisagem sonora", cujo título é "A afinação do mundo", chama a atenção para o fato de que nas paisagens sonoras caracterizadas pelas baixas frequências (a exemplo das ondas quando quebram na praia, as partidas dos aviões nos céus ou mesmo a música popular com seus amplificadores graves e potentes), o ouvinte está imerso no som. Ou seja, "o ouvinte se acha no centro e limitações dos fatores humanos), e sim no que denominam "pensar espaçomotor", que acontece na interação entre os movimentos físico-corporais dos tocadores e a morfologia dos instrumentos. Nessa perspectiva, a produção sonora e a cognição musical

são relacionadas ao corpo

humano, ao corpo do instrumento e ao espaço. É nessa interação que o fazer e 0 pensar musical são realizados. Ao observar como, na guitarra de blues, a disposição das notas pelas seis cordas do instrumento possibilita e incentiva determinados modos (arranjos) de tocar, Baily e Driver relativizam a própria centralidade da dimensão sonora como o meio principal de pensamento e cognição musical: "The hypothesis that this arrangement encourages spatial thinking suggests that musical patterns are remembered and executed not solely as aural patterns but as sequences of movement patterns which have visual, kinaesthetic, tactile, as well as auditory repercussions" (1992: 61).

25 O fenômeno do cromatismo, para Lévi-Strauss, é associado aos pequenos (e minúsculos) intervalos (visuais ou sonoros). Em sua concepção, ao invés da produção de separações e distinções de domínios (como ocorre nos grandes intervalos), os pequenos intervalos estabelecem continuidades $\mathrm{e}$ passagens. $O$ exemplo do arcoíris é lembrado diversas vezes ao longo das "mitológicas" (especialmente no tomo I,

"O cru e o cozido"), a fim de exemplificar as misturas, passagens e justaposições geradas a partir dos pequenos intervalos cromáticos.

Enquanto o cromático (na música e na pintura) lida com pequenas variações $\mathrm{e}$ intervalos, o diatônico salienta os grandes intervalos, as descontinuidades e separações mais ou menos bem definidas. As pequenas diferenças fazem do cromático, ainda de acordo com Lévi-Strauss, uma fonte de perigo, instabilidade e busca: "É como se o pensamento sul-americano, decididamente pessimista por sua inspiração, diatônico por sua orientação, atribuísse ao cromatismo uma espécie de maleficência original, tal que os grandes intervalos, indispensáveis na cultura para que ela exista, e na natureza, para que o homem possa pensá-la só possam resultar da autodestruição de um contínuo primitivo cuja força ainda se faz sentir nos 
do som; é massageado por ele, inundado por ele" (op. cit.: 170). Já nos ambientes acústicos marcados pelas médias e altas frequências (sendo a sala de concerto o caso exemplar), o ouvinte experimenta o som como algo exterior a ele, localizável no espaço e distinguível em suas variações. Independentemente das críticas que podemos direcionar ao modelo de Schafer, seja pelo seu esquematismo ou por sua concepção reificada e excessivamente visualizada da categoria "paisagem" (Ingold, 2015), a ideia de um som grave como propulsor de determinadas experiências auditivas me parece instigante para pensar o caso das folias.

Nessa correlação, podemos dizer que a categoria baixão, como uma espécie de eixo sonoro em torno do qual a afinação e o sistema musical das folias se organizam, aponta para uma experiência sonora (ou modo de audição) que enfatiza justamente o envolvimento, a continuidade e a imersão. O baixão, no pensamento musical (ou "musicológica") dos foliões, é um som que penetra, mistura, veicula, preenche de tal modo o ambiente com a sua presença que ele próprio se torna o ambiente, inundando a todos com sua frequência regular, constante, simultânea e ordenada.

\section{AMEAÇAS, RISCOS E RUPTURAS}

O consenso, equilíbrio e estabilidade almejados (que a categoria baixão parece bem expressar) são provisórios, tênues e frágeis como as cordas de uma viola. Sofrem a ameaça de serem rompidos a toda e qualquer hora - o que revela o risco constante da afinação não ser bem-sucedida, de não dar certo. Empresa arriscada e incerta, a afinação está sujeita aos perigos, às “impurezas" e "contaminações" (Mary Douglas, 1976 [1966]) ou "infelicidades" (Austin, 1962).

Desse modo, afinar revela uma dupla natureza: de um lado, seu propósito é criar ordem, estabilidade, integração e coesão a partir de um ideal sonoro de equilíbrio. Afinal, como dizia o saudoso folião, "o som de um instrumento não deve roubar o som do outro"; além disso, afinar também é lidar com o desconhecido, com o perigo e com o mal que sempre está à espreita. Na região pesquisada, as ações que desestabilizam a afinação das folias são conhecidas como atrapalho, malinagem e feitiço. Em geral, são ações intencionais de determinadas pessoas movidas pela inveja e que direcionam ritos (privados e secretos) para determinados instrumentos musicais. Não por acaso, justamente os instrumentos de corda, incluindo as caixas e as vozes dos cantadores.

À guisa de ilustração e já encaminhando para o final dessa prosa, vou mencionar algumas situações por mim vivenciadas ou para mim narradas que apontam para os perigos, conflitos e tensões inerentes ao universo das folias. Contingências que atuam diretamente na afinação dos instrumentos ou nas vozes dos cantadores. A narrativa que se segue foi a mim relatada por Zé de Júlio, folião que me hospedou durante a minha última incursão em campo, entre dezembro de 2018 e janeiro de 2019. Estava na casa de meu hospedeiro em uma tarde chuvosa quando surgiu a conversa sobre raros pontos em que ainda sobreviveu: ou em proveito do homem, na forma dos venenos que veio a comandar; ou contra ele, no arco-íris, que não pode controlar" (2004 [1964]:321). A afinação, construída na relação entre o som das cordas por meio do tensionamento e da busca contínua por pequenas diferenças, pode ser pensada como um exemplo de cromatismo.

26 | Para Schutz, uma das formas de existência temporal da música é a sua mensurabilidade, a possibilidade de sua divisão subdivisão em temporalidades homogêneas: "Ofcourse,

playing an instrument, listening to a record, reading a page of music all these events occurring in outer time, the time that can be measured by metronomes and clocks, that is, the time that musician 'counts' in order to assure the correct 'tempo' (op.cit.:171). A dimensão temporal associada à cronometria (medição dos intervalos), veiculada ao tempo exterior de um relógio (ou metrônomo), está presente na afinação quando se observa que a prática, por mais cuidadosa e durável, não pode (ou não deve) se prolongar indefinidamente.

27| Nesse sentido, a afinação nas folias parece ampliar as observações feitas por Oliveira Pinto (2001), quando diz que: "Diferente de ritmo ou mesmo de configurações melódicas, as estruturas de afinação e de combinação de intervalos já apresentam uma disposição vertical. Por resultarem de simultaneidades sonoras, os aspectos verticais de toda música são, muitas vezes, mais difíceis de perceber do que os horizontais, que se estendem ao longo da linha temporal. A este domínio vertical de estruturas sonoras pertencem as afinações de instrumentos" (2001: 241). 0 que estamos vendo no caso da folia é que a afinação, além de situar-se na verticalidade e na simultaneidade dos sons que podem ser percebidos no acorde final, também se desenrola na temporalidade, na sucessão e no movimento de sons sequenciais. 
os atrapalhos, malinagens e feitiços nas folias. Como me interessava pelo assunto, dei corda ao meu anfitrião. Ele me contou o seguinte causo. Transcrevo-o diretamente do meu caderno de campo:

Martinho Capeta era o guia, Seu Martinho (meu anfitrião durante a maior parte do meu trabalho de campo) o contra-guia (ou "pegador de verso"). Era uma folia para Bom Jesus, debaixo de um sol quente e seco. Estavam cantando em uma casa quando chega um homem, parece que de uma família de feiticeiros afamados na região. Diz que o homem jogou um feitiço na folia que os instrumentos desafinaram de uma só vez. A voz de seu Martinho sumiu, calou. Daí continuaram o canto, terminando como deu. Na próxima casa, "acertaram" os instrumentos no jeito e começaram mais um cantorio. Até que principiou no prumo, mas com o tempo ficou tudo esbagaçado. Ao final, Zezinho (filho de seu Martinho e liderança religiosa na comunidade) resolveu procurar uma curandeira no Riacho Fundo (localidade vizinha à Taboquinha). Levou uma pinga para ela e contou o ocorrido. A velha curandeira mirou a garrafa de pinga e lá dentro avistou a figura de um homem, o tal que causou o infortúnio para a folia. Disse ainda que era gente próxima que fez a malinagem e que como defesa, os foliões todos, antes de iniciar o canto, deveriam se reunir e cada um tomar um gole do líquido por ela abençoado. Dito e feito! Todos beberam da pinga que a velha preparou e a folia aos poucos foi voltando ao prumo.

Acompanhando a narrativa de Zé de Júlio, percebe-se como os riscos, ameaças e perigos estão sempre à espreita das folias. Como escutei diversas vezes, assim como os Reis Magos tiveram que lidar com o mal personificado na figura de Herodes, cuja intenção era perseguir e matar Jesus, os foliões também entram em contato com essas forças durante os giros. As tensões, conflitos e perigos são constantes em uma folia. Por isso, a atenção e o cuidado devem ser redobrados. Ainda seguindo a narrativa do folião, vemos que o feitiço não é direcionado somente aos instrumentos musicais, desafinando-os, mas também às vozes dos cantadores. Ficamos sabendo ainda que todo feitiço (ou ataque) tem um contrafeitiço (defesa).

Durante a pesquisa de campo, especialmente em folias localizadas na margem esquerda (ou oeste) do São Francisco, deparei-me com algumas situações em que os foliões procuravam se defender contra possíveis ataques dessa natureza. Eles buscavam se prevenir, eliminando (ou reduzindo) o poder e eficácia desses perigos. Assim, é costume nessa região que os foliões produzam o chamado remédio - um composto de raízes e plantas introduzido em uma garrafa que será usada para colocar a cachaça oferecida para folia.

Os foliões durante o giro só devem beber o preparado, que atua tanto no plano orgânico (ajudando por exemplo na digestão de uma comida pesada ou na sustentação da voz do cantador, castigada diante do seu uso intenso e prolongado) quanto espiritual (defendendo dos atrapalhos, malinagens e feitiços). Em algumas 
folias que acompanhei, o remédio era transportado em um embornal ou sacola e conduzido pelos alferes, os encarregados de levar a bandeira e os responsáveis pela repartição da pinga ${ }^{28}$.

A respeito desse assunto, transcrevo um trecho da entrevista que fiz em agosto de 2005 com seu João, alferes de folia e irmão do guia Rivalino, ambos moradores do Pau d'Óleo, localidade à margem esquerda do São Francisco, na beira do rio Pardo:

Em minha folia nós não bebe pinga branca não! Já é preparada, a gente prepara ela antes ... Ali põe um mucado de raiz, põe aquela unha danta, essa quina rosa, coloca mel de Jataí, pra mode não enrrocar, canela, cravo ... coloca no apreparo alí que ela fica gostosa ... Tem que por três ou nove, não põe par não, deixa uma solteira. Ali tira a rapa de um pau, tira de outra até formar nove raiz, aí machuca ela todinha, coloca no litro, chega aqui em casa vem um litro de pinga, eu como encarregado panho de lá e coloco pra dar pros meus companheiros. Os folião só tomam dessa pinga.

E ela corta algum atrapalho?

Ela corta, tem um dizer que diz que corta, mas eu não sei se corta não, né? A gente faz umas invocação que não bebe limpa, porque diz que enrroca e tal, bebe uma pinga aqui de uma qualidade, ali de outra. E ela tando com apreparo já pega aquele costume que a pinga fica de um tempero sozinha.

$\mathbf{2 8} \mid$ Nos termos de Douglas, poderíamos dizer que o consumo do remédio durante o giro seria uma prática ordenadora, que limpa, purifica e defende os foliões contra as ameaças, os perigos e impurezas advindos dos atrapalhos, malinagens e feitiços. Em suas reflexões sobre as relações entre ordem (pureza) e desordem (impureza) nas crenças, práticas e dinâmica das acusações de feitiçaria e magia, a antropóloga, pensando especialmente a segunda categoria, esclarece que: "Tal como a conhecemos, a impureza é essencialmente desordem. A impureza absoluta só existe aos olhos do observador. Se nos esquivamos dela, não é por causa de um medo covarde nem de um receio ou de um terror sagrado que sintamos. As ideias que temos da doença também não dão conta da variedade das nossas reações de purificação ou de evitamento da impureza. A impureza é uma ofensa contra a ordem. Eliminando-a, não fazemos um gesto negativo; pelo contrário, esforçamo-nos positivamente por organizar o nosso meio" (op.cit.: 6-7).

\section{CONSIDERAÇÕES FINAIS}

A afinação, que vimos ser uma prática coletiva na qual múltiplos meios expressivos e sensoriais são combinados e mobilizados, é uma ação, um evento, uma performance que transforma o ambiente e as pessoas. Ela produz sintonia e gera "enquadramentos", estabelecendo vínculos e conexões diversas. A partir do relato etnográfico, a natureza relacional da afinação pode ser percebida em múltiplos planos:

1) no âmbito das relações sociais: vimos como a afinação cria proximidade e engajamento entre as pessoas, reunindo-as e viabilizando um sentimento de pertencimento e experiência de coletividade;

2) no plano sensorial: a afinação mobiliza os sentidos da audição, visão e tato, produzindo assim nos participantes uma experiência sinestésica e multissensorial;

3) 3no âmbito do processo ritual: ela articula diferentes momentos da sequência de uma folia, sendo um importante elo para a passagem entre a caminhada dos foliões de uma casa a outra e a movimentação no interior das casas;

4) no plano das temporalidades: a afinação articula o tempo cronológico, tal como manifesto quando cada folião individualmente acerta corda a corda de 
seu instrumento, com o tempo sincrônico, simultâneo e interno, vivenciado coletivamente no momento em que todos juntos executam um mesmo acorde; no plano cosmológico: afinar é se envolver em um embate com forças e potências de bem e mal, do puro e impuro, da ordem e desordem, das continuidades e rupturas, das consonâncias e dissonâncias.

Como acompanhamos ao longo do artigo, afinar é mover (pôr em movimento) palavras, corpos, objetos e principalmente sons em busca de um limiar que transforma o fluxo das interações - da informalidade, descontração e dispersão observadas na chegada à seriedade, concentração e formalidade presentes no canto, momento de maior solenidade e sacralidade da visita. No entanto, a afinação, enquanto produção de "enquadramento" (frames nos termos de Bateson) e a experiência coletiva (semelhante ao que Tambiah nomeia de "orquestração interpessoal" e Schutz de "sintonia mútua no relacionamento"), é uma empresa arriscada, perigosa, suscetível a inúmeros imponderáveis e "infelicidades" (Ausitn, 1962) que, no limite, pode não dar certo.

Desse modo, a natureza do "enquadre" (frame) na afinação, é sempre uma busca, um devir. Nesse sentido, deveríamos problematizar, ainda com Bateson, a própria ideia de frame em suas dimensões físicas e concretas (em sua conotação de limite, como uma linha que separa de modo mais ou menos preciso um dentro de um fora, um interior de um exterior) ${ }^{29}$.

$\mathrm{Na}$ afinação das folias, como vimos, o "enquadramento" é sempre provisório e instável. Ainda que compreendida com uma espécie de "contexto interpretativo", cuja intenção é ordenar e direcionar (sintonizar) a percepção dos participantes para um "enquadre" que valoriza o dentro (em que a percepção é intensificada) em detrimento do fora (percepção inibida), a afinação, mesmo com mensagens subliminares, como: "Preste atenção no que está dentro e não preste a atenção no que está fora" (Bateson, op.cit: 43), não é imune aos perigos, incertezas e paradoxos. Pois a separação nunca é absoluta. Existem fios, ligações, contágios, nexos, mediações e múltiplos entrelaçamentos.

Afinar, portanto, é produzir envolvimento, sintonia, orquestração em um mundo atravessado por ameaças, incertezas e riscos. Afinal, como repetia Riobaldo que, no Grande Sertão Veredas, de Guimaraes Rosa, andava pelas mesmas regiões por onde caminham os foliões que nos acompanharam até agora: "Viver é mesmo muito perigoso".

Wagner Diniz Chaves é antropólogo, professor do Departamento de Antropologia Cultural do Instituto de Filosofia e Ciências Sociais da Universidade Federal do Rio de Janeiro (DAC/IFCS/UFRJ) e do Programa de Pós-Graduação em Sociologia e Antropologia (PPCSA) da mesma universidade.

29|A perspectiva de Simmel sobre os sentidos e funções da "moldura" nas obras de arte também parece indicar aberturas para problematizarmos o caráter fixo e limitador das "molduras" e "enquadramentos". Nessa direção, no ensaio "A moldura, um ensaio estético", publicado em 1902, Simmel observa um processo de mudança nos sentidos e funções da "moldura" ao longo da história da arte-do período clássico, quando a obra de arte era concebida como uma realidade integrada, autônoma e autossuficiente "um ser em si mesmo, uma totalidade, um mundo fechado que se isola do exterior", a "moldura" funcionava como o mecanismo de reforço dessa unidade, independência e separação da obra em relação ao que Ihe era exterior, ao período moderno, quando a obra de arte enquanto totalidade se dissolve e se torna parte de outras totalidades. Para essa situação contraditória da obra de arte (integral em si, mas que precisa formar com o ambiente exterior outra totalidade), Simmel percebe uma mudança na função da "moldura". Esta deixa de ser um limite entre mundos e passa a desempenhar a tarefa de mediação. Nas palavras do autor: "A obra de arte se encontra na situação contraditória de ter de formar, junto com seu ambiente, um todo integral, já sendo, em si mesma, um todo; repete-se nisso a dificuldade geral da vida em que elementos de totalidades reivindicam uma autonomia própria. É evidente que a moldura precisa ser considerada sutilmente através de avanços e recuos, energias e retardações para que pela visão possa cumprir sua tarefa dentro do visível de mediar entre a obra de arte e seu ambiente, através da criação de vínculos e sua dissolução - tarefa esta em cuja analogia histórica o indivíduo e a sociedade consomem reciprocamente" (Simmel, 2016 [1902]:173). 
CONTRIBUIÇÃO DE AUTORIA: Não se aplica

FINANCIAMENTO: Não se aplica

\section{REFERÊNCIAS BIBLIOGRÁFICAS}

AMES, Eric. 2003. "The sound of evolution". Modernism /Modernity, v.10, n.2: 297-325. https://doi.org/10.1353/mod.2003.0030

ANDRADE, Mário de. [1928] 1972.

Ensaio sobre a música brasileira. São Paulo, Martins Fontes.

ARAGÃO, Pedro de Moura. 2005. Luiz Heitor Corrêa de Azevedo e os Estudos de Folclore no Brasil: uma análise de sua trajetória na Escola Nacional de Música (1932-1947). Rio de Janeiro, Dissertação de Mestrado, Universidade Federal do Rio de Janeiro.

AUSTIN, John L. 1962. How to do Things With Words. Cambridge: Harvard University Press.

AZEVEDO, Luiz Heitor Corrêa de. 1950. "Violas". In AZEVEDO Luiz Heitor Corrêa de. (org.), Relação dos discos gravados no estado de Goiás. Rio de Janeiro, Centro de Pesquisas Folclóricas, n.2, pp. 34-38.

BAILY, John e DRIVER, Peter. 1992. "Spatiomotor thinking in playing folk blues guitar". The world of music, v. 34, n. 3: 57-71. https://www.jstor.org/stable/43563264

BARROS, Felipe. 2013. Música, etnografia e arquivo nos anos 40: Luiz Heitor Correa de Azevedo e suas viagens a Coiás (1942), Ceará (1943) e Minas Gerais (1944). Rio de Janeiro, Multifoco.

BASTOS, Rafael José de Menezes. 1993. "Esboço de uma teoria da música: para além de uma antropologia sem música e de uma musicologia sem homem". Anuário Antropológico, Brasília, v. 18, n.1: 9-73.

BATES, Eliot. 2012. "The social life of musical instruments". Ethnomusicology, v. 56, n. 3: 363-395. https://doi.org/10.5406/ ethnomusicology.56.3.0363

BATESON, Gregory. [1972] 2000. "Uma teoria sobre brincadeira e fantasia". Cadernos IPUB, v. 5: 35-49.

BAUMAN, Richard. 1977. Verbal art as performance. Massachusetts, Newbury House Publishers.

BAUMAN, Richard \& BRIGGS, Charles L. 1990. "Poetics and performance as critical perspectives on language and social life". Annual Review of Anthropology, v. 19: 59-88. https://doi.org/10.1146/ annurev.an.19.100190.000423

BITTER, Daniel. 2010. A bandeira e a máscara: a circulação de objetos rituais nas Folias de Reis. Rio de Janeiro, 7 Letras.

BLUM, Stephen. "Analysis of musical style". In, MEYER, Helen. (org.), Ethnomusicology: an introduction, New York and London, W. W. Norton \& Company, pp.165-213.

BRANDÃO, Carlos Rodrigues. 1977. "A Folia de Reis de Mossâmedes". Cadernos de Folclore, v. 20 Rio de Janeiro, FUNARTE. 
BRANDÃO, Carlos Rodrigues. 1981. Sacerdotes da viola. Petrópolis, Vozes.

CHAVES, Wagner. 2009. A bandeira é o santo e o santo não é a bandeira: práticas de presentificação do santo nas Folias de Reis e de São José. Rio de Janeiro, Tese de Doutorado, Museu Nacional da Universidade Federal do Rio de Janeiro.

CHAVES, Wagner. 2014a. "Canto, voz e presença: uma análise do poder da palavra cantada nas folias nortemineiras". Mana - Estudos de Antropologia Social, v. 20, n. 2:, 249-280. https://doi. org/10.1590/So104-93132014000200002

CHAVES, Wagner. 2014b "A origem da folia de reis na tradição oral: variações de um mito". In: OLIVEIRA, Humbertho. (org.), Mitos, folias e vivências. Rio de Janeiro, Mauad / Bapera, pp 65-88.

CHAVES, Wagner. 2020. "Tudo é e não é": paradoxos e antinomias no pensamento de Riobaldo e no imaginário de violeiros do vale do São Francisco, norte de Minas Gerais". Religião \& Sociedade, v. 40, n. 2: 75-97. https://doi. org/10.1590/0100-85872020v40n2capo4

CHAVES, Wagner e FONSECA, Edilberto. 2005. Sons de couros e cordas: instrumentos musicais tradicionais de São Francisco, MC. Rio de Janeiro, Iphan/CNFCP, 4opgs.

DE VALLE, Sue. 1990. "Organizing organology". Selected reports in ethnomusicology, v. 9: 1-34.

DOUGLAS, Mary. [1966] 1976. Pureza e perigo. São Paulo, Perspectiva.

ELLIS, Alexander. 1885. "On the musical scales of various nations". Journal of the royal society of arts, v. 33: 485-527.
EVEREST, F. Alton; POHLMANN, Ken. 2009. Master Handbook of Acoustics. New York, McGraw Hill.

GOFFMAN, Erving. 1974. Frame

Analysis. New York, Harper \& Row.

HENNION, Antoine. 2003, "Music and mediation: toward a new sociology of music". In CLAYTON, Martin; HERBERT, Trevor. MIDDLETON, Richard. (orgs.), The Cultural Study Of Music: a critical introduction. London and New York, Routledge, pp.80-92.

HENNION, Antoine. 2011. "Pragmática do gosto". Desigualdade \& diversidade, v. 8: 253-277.

HOLANDA, Sergio Buarque de. [1936] 1978. Raízes do Brasil. Rio de Janeiro, José Olympio.

HORNBOSTEL, Erich e SACHS, Curt. [1914] 1961. "Classification of musical instruments". Galpin society jornal, 14, 3-29.

INGOLD, Tim. [2011] 2015. "Quatro objeções ao conceito de paisagem sonora". In: INGOLD, Tim. Estar Vivo: ensaios sobre movimento, conhecimento e descrição. Petrópolis, Vozes, pp. 206-210.

IRVING, David. 2009. "Comparative organography in early modern empires". Music \& Letters, v. 90, n.3: 372-398. https://doi.org/10.1093/ml/gcpo10

JAKOBSON, Roman. [1960] 1973. "Lingüística e poética”. In: JAKOBSON, Roman. Lingüística e comunicação. São Paulo, Cultrix, pp.118-162.

LEVI-STRAUSS, Claude. [1964] $2004.0 \mathrm{cru}$ e o cozido. São Paulo, Cosac \& Naify.

MALINOWSKI, Bronislaw. [1922]

1978. Argonautas do pacífico ocidental. São Paulo, Abril. 
MALINOWSKI, Bronislaw. [1930] 1972. “O problema do significado em linguagens primitivas". In OCDEN \& RICHARDS, A. (orgs.), O significado de significado. Rio de Janeiro, Zahar, pp. 295-330.

MAUSS, Marcel. [1925] 2003. "Ensaios obre a dádiva: forma e razão da troca em sociedades arcaicas". In MAUSS, Marcel, Sociologia e antropologia. São Paulo, Cosac \& Naify, pp.185-314.

MENDONÇA, Cecília. 2012. A coleção Luiz Heitor Corrêa de Azevedo: música, memória e patrimônio. Rio de Janeiro, Dissertação de Mestrado, Universidade Federal do Estado do Rio de Janeiro.

NETTL, Bruno. [1983] 2005a. The Study of Ethnomusicology: twentynine issues and concepts. Urbana e Chicago, University of Illinois Press.

NETTL, Bruno. 2005b. "A year of anniversaries". SEM Newsletter, v.39, n.3, p.5.

OLIVEIRA PINTO, Tiago de. 2001. "Som e música. Questões de uma Antropologia Sonora". Revista de Antropologia, v. 44, n.1: 222-286. https://doi.org/10.1590/ So034-77012001000100007

OLIVEIRA PINTO, Tiago de. 2004. "Cem anos de etnomusicologia e a 'era fonográfica' da disciplina no Brasil". Anais do II Encontro Nacional de Etnomusicologia, Salvador, Contexto, pp. 103-124.

PEREIRA, Luzimar. 2012. Os giros do sagrado: um estudo etnográfico sobre as folias em Urucuia, MG. Rio de Janeiro, 7Letras.

PEREIRA, Luzimar. 2014. 'O 'giro' dos outros: fundamentos e sistemas nas folias de Urucuia, MG." ManaEstudos de Antropologia Social, v.
20, n.3: 545-573. https://doi.org/10.1590/ So104-93132014000300005

PITT-RIVERS, Julian. [1977] 2012. "The law of hospitality". HAU: journal of ethnographic theory, v. 2, n. 1: 501-517.

REILY, Ana Suzel. 2002. Voices of the magi: enchanted journeys in southeast Brazil. Chicago studies in ethnomusicology, The University of Chicago Press.

ROSA, João Guimarães. [1956] 1985. Grande sertão: veredas. Rio de Janeiro. Nova Fronteira.

SCHAFER, R. Murray. [1977] 1997. A afinação do mundo. São Paulo, Editora Unesp.

SCHUTZ, Alfred. [1951] 1976. "Making music together". In BRODERSEN, Arvid. (ed.), Collected papers II: studies in social theory. The Hague, Martinus Nijhoff, pp.159-178.

SEEGER, Anthony. 1987. "Novos horizontes na classificação dos instrumentos musicais". In RIBEIRO, Darcy. (org.), Arte índia: suma etnológica brasileira, vol.3, Petrópolis, Vozes, pp.173-179.

SIMMEL, Georg. [1902] 2016. "A moldura: um ensaio estético". In VILLAS BÔAS, Claucia e OELZE, Berthold. (orgs.), Arte e vida: ensaios de estética sociológica. São Paulo, Hucitec Editora, pp.167-173.

SMALL, Christopher. 1998. Musicking: the meanings of performance and listening. Middletown, Wesleyan University Press.

STOLLER, Paul. 1989. The Taste Of Ethnographic Things: the senses in Anthropology.

University of Pennsylvania Press.

TAMBIAH, Stanley ]. [1979] 1985. "A performative approach to ritual". In: TAMBIAH, Stanley ]. Culture, Thought, And Social Action: an anthropological perspective. Cambridge, Harvard University Press, pp. 113-169. 
TRAVASSOS, Elizabeth. 1987. “Glossário dos instrumentos musicais". In RIBEIRO, Darcy. (org.), Arte índia: suma etnológica brasileira, vol.3, Petrópolis, Vozes, pp.180-187.

TURNER, Victor. [1967] 2005. “Betwix and between: o período liminar nos 'ritos de passagem'". In Floresta dos símbolos: aspectos do ritual Ndembu. Niterói, EdUFF, pp.137-158.
TURNER, Victor. [1969] 2013. "Liminaridade e communitas". In O processo ritual: estrutura e antiestrutura. Petrópolis, Vozes, pp.97-126.

VAN GENNEP, Arnold. [1908] 2011. Os ritos de passagem. Petrópolis, Vozes.

WISNIK, José Miguel. 1989. O som e o sentido. São Paulo, Companhia das Letras.

Recebido em 21 de outubro de 2019. Aceito em 25 de novembro de 2020. 